Article

\title{
Needs Assessment of an Ethnic Chinese Community in Japan
}

\section{Li-Mei Chen}

School of Human Welfare Studies, Kwansei Gakuin University, 1-155 Ichibancho, Uegahara, Nishinomiya 662-8501, Japan; E-Mail: limei@kwansei.ac.jp; Tel./Fax: +81-798-54-6323

External editor: Martin J. Bull

Received: 17 May 2014; in revised form: 14 August 2014 / Accepted: 10 September 2014 / Published: 26 September 2014

\begin{abstract}
This study is a needs assessment of ethnic Chinese older adults in Japan. The Delphi method was applied to identify the needs addressed by the focus groups. Maslow's hierarchy of needs model guided the examination of the community's political, economic and social environment in satisfying the needs of older community members. The needs were matched with a city's Health, Welfare, and Long-term Care Insurance Program Plan seeking to identify differences between ethnic Chinese and Japanese community members. Most of the needs were similar to those of the Japanese citizens, but there were a few issues related to financial and cultural needs that were unique to the ethnic Chinese group.
\end{abstract}

Keywords: Chinese; Japan; long-term care insurance; needs assessment; older adults

\section{Introduction}

Numerous studies have been documented on the utilization of health and long-term care service by racial and ethnic older adults. Barriers hindering service utilization across racial and ethnic groups have become a national concern in countries like the United States as it was found to contribute to the disparities in older adults' health, mental health, and quality of life outcomes [1]. Barriers to service use are complex: discrimination in healthcare settings [2], segregation of long-term care services by race [3,4], different beliefs in manifestation of illnesses [5], and healthcare decisions [5,6] are some of the contributing factors related to disparities of service use among racial and ethnic groups.

Unlike in the West, there are very few Japanese studies on service use by minorities, let alone racial and ethnic older adults. Moreover, the extent of Japan's racial and ethnic diversity is unclear because there is no public information on racial and ethnic statistics in Japan. From the information that is 
available, we know that the total foreign population in Japan comprises only 1.7 percent of Japan's total population of 127 million [7]. The presence of foreigners is visibly identifiable by the various large and small ethnic enclaves created across the country by Koreans, Brazilians, Indians, Americans, Chinese, and others. There are also a limited number of second-generation immigrants and beyond who have naturalized as Japanese citizens. A steady stream of applications is accepted each year; in 2011, about 11,000 applications were accepted for naturalization [8]. Once accepted, some naturalized citizens adopt a Japanese name instead of keeping their original name to avoid discrimination.

Available studies on health service use among foreigners or naturalized citizens in Japan report mixed findings. The findings on the evaluation of care for older ethnic Koreans suggest a lack of culturally sensitive care for ethnic Korean older adults [9-13], while others suggest that highly acculturated ethnic Koreans are capable of accepting mainstream Japanese long-term care services [14,15]. Studies on foreign laborers in Japan show that many are uninsured despite the fact the law mandates all foreigners who stay for more than one year to enroll in the national health insurance program $[16,17]$. Sugimoto and colleagues' study on foreign laborers [17] found that the correlates of being uninsured were lack of knowledge about insurance, absence of chronic illness, and having one or no children. Lack of interpreters, translated medical documents, and information in general have also been reported as hindering service use by foreigners in Japan [16,18]. Extraneous health expenses accompanying delayed service use also seems to be a problem. A study comparing Japanese and foreign dentistry patients found that the average fee for foreigners was significantly lower than for the Japanese, but their out-of-pocket costs were higher [19]. The study concluded that foreign patients tended to put off a dentist visit unless it was urgent since they felt that the fees were too expensive for them.

Use of services is important in order to secure basic needs for good health. Unless basic physical needs are met, it is difficult to reach more complex social and personal needs, such as self-esteem and self-actualization, which improve quality of life - a goal for most members of a given society.

Maslow's theory helps us understand this concept that our quality of life (QOL) is a developmental task that involves satisfying needs in a hierarchical manner starting from the most basic physiological need to an ever more complex social and personal needs [20]. Maslow's hierarchy of needs is stratified into 5 levels: the lowest order need is biological and physiological needs such as air, food, drink, shelter, and sleep; the second level is safety and security of resources, employment, health, and order; the third level is belongingness and love such as family, sexual intimacy, and friendship; the fourth level is esteem such as self-esteem, achievement, confidence, respect of others and respect by others; and the highest level is self-actualization such as morality, spontaneity, problem solving, and lack of prejudice. The levels can be further divided into two: basic (or deficiency) needs including the first four lower level needs, and growth needs including the highest level needs. One must satisfy the lower basic needs before progressing onto meeting higher level growth needs [21].

Maslow's theory remains appealing because it can help identify whether a certain group of individuals are at a dire stage with unmet basic needs. As Angel and colleagues eloquently said, it "...draws attention to the major obstacles that marginalized and powerless individuals face in their progress toward full material and psychological security" [22]. The authors further state that marginalized groups often lack the ability to satisfy the more basic deficiency needs in Maslow's hierarchy due to structural reasons. Moreover, previous studies report that health and welfare service models were created by identifying needs based on Maslow's theory [23,24]. In other words, Maslow's 
theory can serve as an indicator to determine the type of needs identified by a racial and ethnic group living in Japan in order to create appropriate services to achieve a satisfactory quality of life.

\subsection{Ethnic Chinese Older Adults in Yokohama, Japan}

Approximately 2.1 million foreigners are currently living in Japan, and about $80 \%$ are from Asian countries [25]. A third of the applicants for naturalization are of Chinese descent [26]. The City of Yokohama has the second largest ethnic Chinese community with a commercial and residential district, "Chinatown," in the heart of the city. Since there are no official data available reporting the actual number of ethnic Chinese living in Yokohama, the population can only be assumed by combining two separate data. First, the largest number of foreign nationals living in Japan is Chinese (kakyo), comprising of approximately 680,000 persons. According to the 2009 census of registered foreigners, the number of ethnic Chinese has declined for the first time since the census was taken $(-1.4 \%$, or 31,305 persons), but has remained steady at about 650,000 persons until the latest figures in 2012 census. Yokohama has approximately 33,000 Chinese living there, following 132,000 Chinese living in Tokyo, the capital of Japan. Most of the Chinese in Yokohama live in Naka Ward where "Yokohama Chinatown" is located. According to the prefectural data, registered Chinese are mostly young persons; persons aged 60 years and older make up only $4 \%$ of them. However, the number of older adults has grown steadily in recent years; in 2010, there were 2,339 Chinese adults aged 60 years and older, which is up $23 \%$ from five years ago.

In addition to the registered Chinese nationals, there are ethnic Chinese with Japanese citizenships or with resident status. There are no data on this group of ethnic Chinese. What is known is that since 2001, there were approximately 3,500 to 5,400 naturalized ethnic Chinese each year. Therefore, in the past 12 years, it can be assumed that there were about 50,000 naturalized ethnic Chinese. The average rate of older adults in Yokohama was $19.5 \%$, so one can assume that there may be about 10,000 naturalized ethnic Chinese aged 65 years and older.

In summation, although most of the foreigners residing in Japan are in their $20 \mathrm{~s}$ to $50 \mathrm{~s}$, there is a steady growth of persons aged 60 and older, which is especially true for the Chinese population (and Korean). Since Asia is one of the fastest aging regions in the world with one in every three persons predicted to be 60 years or older by the year 2050, it is highly possible that there will be more older adults immigrating to Japan or young workers who choose to reside in Japan as a final resting place as their population's longevity extends. In an era of global aging, there is a need to examine the preparedness of Japan's social welfare system in the face of older immigrants.

\subsection{Purpose of the Study}

Based on this background, the purpose of this investigation is to conduct an assessment to clarify the needs and assets of an ethnic community in Japan. This paper will report the findings only from the needs assessment on Chinese older adults which was guided by the following research questions: (1) What are the needs of an ethnic Chinese community facing advanced aging? and (2) How are the needs of an ethnic Chinese community different from or similar to the Japanese society at large? 


\section{Methods}

\subsection{Sample}

The Joint Council for Yokohama Chinatown's Community Development was identified as the largest non-profit network with 23 groups from Yokohama Chinatown representing various stakeholders such as women's groups, neighborhood district associations, professional groups, and groups based on shared provincial hometowns in China. First, invitations to participate in the focus groups were distributed to the member groups of the Joint Council. Requirements for participation included membership with any of the groups from the Joint Council and fulfilling either of the following conditions so they have a certain level of understanding about persons 65 years and older: (1) the participant is an older adult of 65 years or older, or (2) the participant has a family member who is 65 years or older. Based on the number of responses and their availability, six focus groups were formed consisting of at least four but up to eight members.

Focus group interviews were conducted by the primary investigator and other investigators of this study were present at the interviews as observers. Participants gave their consent to have their interviews taped and their demographic profile including name, sex, age, and contact information used for this study. Audio-taped records of the interviews were transcribed in full by a Japanese transcribing company and checked carefully to ensure their accuracy and completeness.

\subsection{Coding Procedure}

Transcriptions were used for coding by the two investigators. The investigators coded individual themes on needs as a unit of analysis in a word, sentence, or paragraphs [27]. Categories and a coding scheme were derived from the previous literature on ethnic minorities' health and long-term care needs and also from the Yokohama City's three-year plan for the long-term care insurance and older adult's wellbeing. The list of needs from the city plan also served as a way to identify the needs which were not addressed by the local government and also as a comparison between the needs of the Japanese and those pertaining only to older ethnic minorities. A peer debriefing process was undertaken to reduce the bias of one researcher and enhance the credibility of the coding. In addition to the interviews, observations and follow-up contacts with study participants served as a triangulation method to verify the codes.

\subsection{Delphi Procedure}

A list of needs was compiled and distributed to the same people who responded to the invitation to participate in this study. The Delphi procedure was used as a method to obtain a reliable consensus in groups. Procedures vary but, in general, Delphi allows participants to freely identify and elaborate issues that they deem important. Later, these issues are consolidated as a structured questionnaire to elicit quantitative measures of the participants' opinions and judgments, as well as a private response to avoid social pressures [28].

Participants were asked to rate on paper their needs by five levels of problem severity: (1) Not a problem; (2) A minor problem; (3) A moderate problem; (4) A severe problem; and (5) A catastrophic problem. Ratings were collected and calculated for median and variance scores for each need. The 
median score provided the study participants' level of problem severity for each need. The variance provided the level of consensus of all participants on the rating of severity level. In other words, if the median score was closer to 5 , the need was more likely to be viewed as a severe problem by the participants, while a median score closer to 1 meant that the need was less likely to be viewed as a problem. Additionally, less variance indicated that the rating of the need gained consensus from the group while a larger variance showed that it was more likely that the rating of the need did not achieve much consensus. The needs were ranked by their priority as a problem along with the levels of consensus achieved by the group for analysis.

\section{Results}

Forty-three members from the 23 groups forming the Joint Council listed their names to participate in the study, but 32 persons (74\%) actually participated in the six focus groups. Table 1 provides the participant characteristics. Three participants did not provide their age, but for those who did, the age range was from 34 to 81 years old, with an average age of 59.1 years old. The majority of the participants were males $(n=24)$ as opposed to females $(n=9)$.

Table 1. Participant Characteristics $(n=32)$.

\begin{tabular}{cc}
\hline Age & N \\
\hline $30 \mathrm{~s}$ & 4 \\
$40 \mathrm{~s}$ & 4 \\
$50 \mathrm{~s}$ & 5 \\
$60 \mathrm{~s}$ & 11 \\
$70 \mathrm{~s}$ & 4 \\
$80 \mathrm{~s}$ & 1 \\
Unknown & 3 \\
\hline Average Age & 59.1 \\
\hline Sex & \\
\hline Female & 9 \\
Male & 24 \\
\hline
\end{tabular}

Based on the focus group interviews, 30 needs were identified from the analysis. To conduct the Delphi, a list of 30 needs were sent to be rated by problem severity by the 43 people who initially agreed to participate in the study. In this part of the study, 38 persons $(88 \%)$ returned their ratings.

Median scores for the 30 needs that indicated the levels of severity of the problem ranged from 1.72 to 3.19 with an average of 2.43 . As a way to facilitate comparisons among topics, numeric priority ratings were grouped by dividing the sum of the values by the number of ratings. This is a procedure that treated nominal scales as interval data [29]. The value 2.43 was regarded as a neutral point, with boundaries distributed accordingly to avoid polarization of scores [30]. Based on the range, needs were grouped by median scores into the following three categories for analysis: low priority $(<2.25)$, moderate priority (2.26-2.6), and high priority $(>2.61)$. As for the variance indicating consensus level of the participants' ratings, variance ranged from 0.4 to 2.05 with an average of 0.85 . A neutral point was also found for the consensus level, and the following three categories were created for the analysis: low consensus $(>0.96)$, moderate consensus $(0.95-0.75)$, and high consensus $(<0.74)$. 
Tables 2 through 4 indicate the needs by level of priority in descending order from high, moderate, and low, and levels of consensus were also arranged in descending order within each priority level. Next to each need item, a corresponding policy measure from the city plan was included if available. Overall, 20 items out of 30 needs addressed by the participants received moderate to high consensus.

Table 2. High priorities, levels of consensus, and corresponding city's policy plan for 30 needs identified from focus group interviews with the ethnic Chinese community.

\begin{tabular}{|c|c|c|c|c|c|}
\hline $\begin{array}{l}\text { Priority } \\
\text { Level }\end{array}$ & Median & Variance & $\begin{array}{l}\text { Consensus } \\
\text { Level } \\
\end{array}$ & Needs & Policy Plan \\
\hline \multirow{10}{*}{ High } & 3.19 & 0.66 & High & 1. Difficulty with shopping & $\begin{array}{l}\text { 7. To provide more } \\
\text { services besides those } \\
\text { covered by the LTC } \\
\text { insurance (p. 136) }\end{array}$ \\
\hline & 3.14 & 0.79 & Moderate & $\begin{array}{l}\text { 2. Unpreparedness for bankruptcy } \\
\text { and other financial risks }\end{array}$ & \\
\hline & 3.05 & 2.05 & Low & $\begin{array}{l}\text { 3. Hesitation to use LTC services due } \\
\text { to pride }\end{array}$ & \\
\hline & 3.00 & 1.03 & Low & $\begin{array}{l}\text { 4. Inability to afford living in } \\
\text { Chinatown }\end{array}$ & \\
\hline & 2.80 & 1.43 & Low & $\begin{array}{l}\text { 5. Lack of support for those } \\
\text { diagnosed with hepatitis } \mathrm{C}\end{array}$ & \\
\hline & 2.77 & 0.56 & High & $\begin{array}{l}\text { 6. Lack of formal caregivers with } \\
\text { ethnic Chinese background or } \\
\text { cultural competency }\end{array}$ & $\begin{array}{l}\text { 5. To secure a diverse } \\
\text { group of care workers } \\
\text { (p. 62) }\end{array}$ \\
\hline & 2.76 & 0.99 & Low & $\begin{array}{l}\text { 7. Hesitation to use health services } \\
\text { due to language and culture }\end{array}$ & \\
\hline & 2.70 & 1.17 & Low & $\begin{array}{l}\text { 8. Lack of older participants in } \\
\text { community programs organized by } \\
\text { local groups }\end{array}$ & $\begin{array}{l}\text { 6. To increase support of } \\
\text { community activities } \\
\text { preventive care (p. } 68 \text { ) }\end{array}$ \\
\hline & 2.67 & 0.53 & High & $\begin{array}{l}\text { 9. Tax system discouraging } \\
\text { charitable and philanthropic activities }\end{array}$ & \\
\hline & 2.67 & 0.63 & High & 10. Loss of traditional family care & \\
\hline
\end{tabular}

High priority with moderate to high consensus. Ten out of 30 items were rated as high priority by the participants (Table 2). Five items received either high or moderate consensus. High priority and high consensus were achieved for the following four items: (1) difficulty with shopping (median[med] $=3.19$, variance[var] $=0.66$ ); (6) lack of formal caregivers with ethnic Chinese background or language ability (med $=2.77$, var $=0.56$ ); (9) tax system discourages charitable and philanthropic activities $(\mathrm{med}=2.67$, var $=0.53)$; and $(10)$ loss of traditional family care $(\mathrm{med}=2.67$, var $=0.63)$. High priority and moderate consensus was received for one item; (2) unpreparedness for bankruptcy and other financial risks ( $\operatorname{med}=3.14$ var $=0.79$ ).

Moderate priority with moderate to high consensus. Moderate priority was given to ten items of which seven items received moderate to high consensus (Table 3). Moderate priority and high consensus was achieved for a single item, (19) lack of space for older adults to congregate. Six items 
received moderate priority and moderate consensus: (11) lack of barrier-free facilities in Chinatown (med $=2.60$, var $=0.88$ ); (12) difficulty gaining support on aging issues since the community is divided into "two Chinas" ( $\mathrm{med}=2.57$, var $=0.86$ ); (13) lack of information on public services $(\operatorname{med}=2.57$, $\operatorname{var}=0.86) ;(17)$ inability to afford health services $(\operatorname{med}=2.45$, var $=0.92)$; $(18)$ lack of support for aging caregivers (med $=2.40$, var $=0.88$ ); (20) socially withdrawn older adults $($ med $=2.27 ; \operatorname{var}=0.78)$.

Table 3. Moderate priorities, levels of consensus, and corresponding city's policy plan for 30 needs identified from focus group interviews with ethnic Chinese community.

\begin{tabular}{|c|c|c|c|c|c|}
\hline $\begin{array}{l}\text { Priority } \\
\text { Level }\end{array}$ & Median & Variance & $\begin{array}{l}\text { Consensus } \\
\text { Level }\end{array}$ & Needs & Policy Plan \\
\hline \multirow{10}{*}{ Moderate } & 2.60 & 0.88 & Moderate & $\begin{array}{l}\text { 11. Lack of barrier-free } \\
\text { facilities in Chinatown }\end{array}$ & $\begin{array}{l}\text { 6. To raise public awareness and } \\
\text { promote civic society (p. 93) }\end{array}$ \\
\hline & 2.57 & 0.86 & Moderate & $\begin{array}{l}\text { 12. Difficulty gaining support } \\
\text { on aging issues since the } \\
\text { community is divided into } \\
\text { "two Chinas" }\end{array}$ & \\
\hline & 2.57 & 0.86 & Moderate & $\begin{array}{l}\text { 13. Lack of information on } \\
\text { public services }\end{array}$ & $\begin{array}{l}\text { 6. Raising public awareness on } \\
\text { health promotion and long-term } \\
\text { care prevention (p. } 67 \text { ) }\end{array}$ \\
\hline & 2.55 & 1.21 & Low & $\begin{array}{l}\text { 14. Lack of support for new } \\
\text { Chinese immigrants and their } \\
\text { older adults }\end{array}$ & $\begin{array}{l}\text { 6. To strengthen the role of the } \\
\text { Social Welfare Council (p. 85) }\end{array}$ \\
\hline & 2.52 & 0.96 & Low & $\begin{array}{l}\text { 15. Lack of support for older } \\
\text { adults with mental health } \\
\text { issues (i.e., depression) }\end{array}$ & $\begin{array}{l}\text { 6. To implement preventive care } \\
\text { based on individual needs (p. } 70 \text { ) }\end{array}$ \\
\hline & 2.52 & 1.06 & Low & $\begin{array}{l}\text { 16. Lack of citizenship and } \\
\text { resident status hindering use of } \\
\text { public services }\end{array}$ & $\begin{array}{l}\text { 6. To raise public awareness on } \\
\text { health promotion and long-term } \\
\text { care prevention (p. } 67 \text { ) }\end{array}$ \\
\hline & 2.45 & 0.92 & Moderate & $\begin{array}{l}\text { 17. Inability to afford health } \\
\text { services }\end{array}$ & \\
\hline & 2.40 & 0.88 & Moderate & $\begin{array}{l}\text { 18. Lack of support for aging } \\
\text { caregivers }\end{array}$ & $\begin{array}{l}\text { 7. To support older adults and } \\
\text { their family caregivers (p. 122) }\end{array}$ \\
\hline & 2.33 & 0.73 & High & $\begin{array}{l}\text { 19. Lack of space for older } \\
\text { adults to congregate }\end{array}$ & $\begin{array}{l}\text { To support social participation } \\
\text { including ikigai activities (p. } 77 \text { ) }\end{array}$ \\
\hline & 2.27 & 0.78 & Moderate & $\begin{array}{l}\text { 20. Lack of support for } \\
\text { socially withdrawn older } \\
\text { adults }\end{array}$ & $\begin{array}{l}\text { 6. To implement preventive care } \\
\text { based on individual needs (p. } 70 \text { ) }\end{array}$ \\
\hline
\end{tabular}

Low priority with moderate to high consensus. Ten needs were rated as low priority and moderate to high consensus was met for eight of the ten items (Table 4). Low priority and high consensus were found in the following five items: (21) lack of support for older adults who lost the ability to speak Japanese due to illness/medication (med $=2.25$, var $=0.72$ ); (23) lack of support for impoverished older women $(\mathrm{med}=2.15$, var $=0.56)$; (29) lack of support for older adults without pensions $(\mathrm{med}=1.76$, var $=0.69)$; (30) lack of support for older adults with physical disabilities $($ med $=1.72$, 
var $=0.4)$. Low priority and moderate consensus were found in three items: (22) lack of jobs for older adults $(\mathrm{med}=2.23$, var $=0.95) ;(25)$ conflicts between old and young family members $(\mathrm{med}=2.05$, $\operatorname{var}=0.75)$; and $(27)$ lack of opportunities for intergenerational exchange $(\operatorname{med}=2.0$, var $=0.86)$.

Table 4. Low priorities, levels of consensus, and corresponding city's policy plan for 30 needs identified from focus group interviews with ethnic Chinese community.

\begin{tabular}{|c|c|c|c|c|c|}
\hline $\begin{array}{l}\text { Priority } \\
\text { Level }\end{array}$ & Median & Variance & $\begin{array}{l}\text { Consensus } \\
\text { Level }\end{array}$ & Needs & Policy Plan \\
\hline \multirow{10}{*}{ Low } & 2.25 & 0.72 & High & $\begin{array}{l}\text { 21. Lack of support for older adults } \\
\text { who lost the ability to speak } \\
\text { Japanese due to illness/ medication }\end{array}$ & $\begin{array}{l}\text { 7. To support older adults with } \\
\text { dementia and their families } \\
\text { (p. 117) }\end{array}$ \\
\hline & 2.23 & 0.95 & Moderate & 22. Lack of jobs for older adults & $\begin{array}{l}\text { 6. To support older adult's work } \\
\text { (p. 80) }\end{array}$ \\
\hline & 2.15 & 0.56 & High & $\begin{array}{l}\text { 23. Lack of support for } \\
\text { impoverished older women }\end{array}$ & \\
\hline & 2.14 & 1.03 & Low & $\begin{array}{l}\text { 24. Lack of support for older adults } \\
\text { without families }\end{array}$ & $\begin{array}{l}\text { 6. To support older adults living } \\
\text { alone/ older adults alone during } \\
\text { the day }\end{array}$ \\
\hline & 2.05 & 0.75 & Moderate & $\begin{array}{l}\text { 25. Conflicts between old and } \\
\text { young family members }\end{array}$ & $\begin{array}{l}\text { 7. To support older adults and } \\
\text { their family caregivers (p. 122) }\end{array}$ \\
\hline & 2.05 & 1.05 & Low & $\begin{array}{l}\text { 26. Local governments creating } \\
\text { "one size fits all" policies for a } \\
\text { lack of better policy }\end{array}$ & $\begin{array}{l}\text { 6. To implement preventive care } \\
\text { based on individual needs (p. } 68 \text { ) }\end{array}$ \\
\hline & 2.00 & 0.86 & Moderate & $\begin{array}{l}\text { 27. Lack of intergenerational } \\
\text { opportunities }\end{array}$ & $\begin{array}{l}\text { 6. To raise public awareness and } \\
\text { promoting a society (p. 93) }\end{array}$ \\
\hline & 1.77 & 0.47 & High & $\begin{array}{l}\text { 28. Fears of physical and mental } \\
\text { decline }\end{array}$ & $\begin{array}{l}\text { 6. To implement preventive care } \\
\text { based on individual needs (p. } 70 \text { ) }\end{array}$ \\
\hline & 1.76 & 0.69 & High & $\begin{array}{l}\text { 29. Lack of support for older adults } \\
\text { without pensions }\end{array}$ & \\
\hline & 1.72 & 0.4 & High & $\begin{array}{l}\text { 30. Lack of support for older adults } \\
\text { with physical disabilities }\end{array}$ & $\begin{array}{l}\text { 6. To link fragmented services } \\
\text { under disability policy }\end{array}$ \\
\hline
\end{tabular}

\section{Conclusions}

The results of the study revealed the needs of ethnic older adults of the Yokohama Chinatown community. As a Delphi study, achieving consensus is an important factor, so priorities with high or moderate consensus receive attention for analysis as they correspond to the Maslowian hierarchy and the city plan.

As shown in Table 2, five out of 10 items received high or moderate consensus. These items addressed level 2 of Maslow's hierarchy, thereby demonstrating that when physical needs were met, people sought to secure resources to treat or prevent physical and emotional harm. None of the other high priority need items were from the lowest order of satisfying older adults' basic needs. The most pressing need which also received the highest consensus was difficulty with shopping (item 1), which corresponds to the second order of securing resources. Chinatown used to have a variety of shops to 
meet the daily needs of local ethnic Chinese residents, but many of these stores have closed in recent years. A participant who knows the past reminisced as follows:

"Shopping has become difficult for Japanese in general, but also for the ethnic Chinese older adults. Indeed, there are supermarkets around their (ethnic Chinese older adults) homes, but shopping in Chinatown was a true pleasure. Shopping in Chinatown was fun because you actually talk and mix with others, and older adults were stimulated from that experience."

Due to the growing aging population coupled with a prolonged stagnant economy, Kaimono nanmin, or "shopping refugees" have become a nationwide problem. In 1990, the Japanese economy burst and went into recession. The economy showed some signs of recovery in the $2000 \mathrm{~s}$, but the Lehman Shock in 2008 worsened Japan's economy in a deflation spiral. Along with the rest of the economy, Yokohama Chinatown has been badly hit by the long recession and many businesses suffered great losses including the worst: going out of business. Ethnic Chinese older adults are also experiencing the same problem. There are older adults who cannot purchase groceries and other retail goods in their local neighborhood because of shops closing down.

Furthermore, securing protection from financial harm is another area which received high priority and moderate consensus (item 2). The possibility of losing your wealth and assets is difficult for anyone, especially if one has not secured one's retirement pension or planned for one's finances in later life. The lack of support for some ethnic Chinese older adults without public pension was also addressed by our participants (item 29). In the past, ethnic Chinese older adults were unable to participate in the national pension system and even after they were allowed to participate in the pension system from 1981, many chose not to participate since they were self-employed and found it too late to join. Employment at old age in Japan is higher compared to other developed countries, but because age discrimination is rampant, older adults are limited to mostly part-time and low paying work [31]. The participants also acknowledge the lack of appropriate jobs available for older adults (item 22). Ethnic Chinese older adults may be more likely to face financial risks in old age compared to Japanese older adults.

Next, there were two items on caregiving issues that received high priority and high consensus. They reflect the need to secure protection from both emotional and physical harm. One identified need was the loss of traditional family care (item 10). The study participants reported that they believed that the inception of the public long-term care insurance program in the year 2000 minimized the idea of filial piety that taught elder care as the responsibility of adult children. Just like the majority of Japanese, long-term care was primarily provided by family members. The data shows that the move from traditional familial care to socialization of care has some effect on how Japanese think about their care. It is still true that even after the inception of the national long-term insurance care program, families are still very much involved in the provision of care [32]. However, an annual national study [33] reported that there was a significant decline from the previous year's results on persons aged 20 and above who agreed that children were obligated to provide care for their parents. The same attitude seemed to become pervasive in the ethnic Chinese community. One study participant lamented that what distinguished their community members from the Japanese was that they had stronger familial bonds, and that has been "tainted" by the introduction of socializing care. 
Another was a lack of formal caregivers with ethnic Chinese background or language ability (item 6). A participant discusses her concern for her mother-in-law's care:

"My mother-in-law is 74 years old and is paying the long-term care insurance premium. I had long talks with the local municipality office that she doesn't speak a word of Japanese. She speaks Shanghainese. I asked the government workers many times whether she will be able to receive appropriate care in this country, they said, 'As long as she has continued to pay the premiums, she has the right and will receive the needed care when the time comes (for long-term care).' I think it's unrealistic. She can't speak a word. She was hospitalized recently, and she was unable to discuss about her treatment or express her needs there because the nurses couldn't speak the language. We had calls all the time from the hospital asking us to interpret over the phone."

Today, the majority of care professionals are Japanese, and they may not fully understand the unique needs of ethnic Chinese older adults. The current care professionals' education and training does not include cultural competency to prepare them with a growing diverse elderly population. Furthermore, Japan's care professionals lack racial and ethnic diversity due to the highly rigid national exam system, which makes it difficult for anyone lacking formal Japanese education to pass the exam. Neighboring Southeast Asian nations like Indonesia and the Philippines have entered into forming a bilateral free trade agreement (Economic Partnership Agreement, EPA) with Japan, and have sent a total of 1,562 formal home health aides or nurses for a stay of up to four years [34]. However, the overall passing rate has been low. In 2012, out of 415 foreign applicants, only 47 passed the exam. With the growing aging population and declining number of Japanese care professionals due to their aging and lack of young people entering the caregiving profession, Japan is pressured to make the decision to deregulate the system to lower the bar for foreign care workers.

Another area that requires deregulation is the taxation system (item 9). Compared to the West, Japan's charitable giving is minute. Difference in cultural views on charitable giving has been pointed out as the reason, but the Japanese tax system has also been blamed for discouraging Japanese from donating money [35]. They may feel strongly about wanting to gain esteem, but the current economy makes it difficult for them to do so. Reflective of Maslow's fourth needs level, this need item raises a point that the community realizes that there are unique needs of their older members but the lack of financial incentives for donating is a concern for them, especially during today's economic recession. They may be conflicted with the inability to fulfill the long-held value of mutual financial support, which undermines the self-esteem of members of the society.

Moderate priorities were different from the high priorities, since they addressed, in many respects, the need for social inclusion. Seven out of ten items received either moderate or high consensus. The inability to access mainstream physical and social resources due to age, disabilities, or legal status was pointed out as a moderate priority. Furthermore, unlike the high priorities, groups within the older adult population were specified - older caregivers taking care of older adults (item 18) and socially withdrawn older adults (item 20) — as requiring attention. These groups are not only specific to the ethnic Chinese population but also among the Japanese, as Japan has now entered the super-aging society. Households with older adults living as a couple or alone are increasing in Japan. According to a 2011 White Paper issued by the Cabinet Office, a survey asking older adults whether they found 
meaning in life (ikigai) showed that approximately 13\% of the respondents found no meaning in life (add numbering). More than a third of them were older men living alone (34.9\%), two times higher than women living alone (15.2\%). Approximately 40\% reported that they rarely have contact with their neighbors. In Tokyo, the number of older adults found dying alone has been increasing steadily, reaching more than 2,000 cases in three consecutive years (2007-2009). As for older adults caring for other older family members, in a national survey conducted in 2013, more than half of the households with older adults requiring long-term care were receiving care from their family members who were 65 years or older (51.2\%) [36]. Both of the specified groups have been identified as at-risk groups in Japan by the national government.

For the ethnic Chinese population, in addition to their ethnic background, they may experience double (with old age) or triple jeopardy (with gender), thereby placing them in a more complex situation of exclusion. However, our results suggest that their situation may be self-inflicted. Facilities within their own community lack barrier-free access (item 11), the political divide within the community hinders them from uniting on aging issues (item 12), and the lack of physical space to congregate (item19) disallows the community to be more socially inclusive among themselves and of older adults.

The eight low priority items with either high or moderate consensus are concentrated in very specific groups within the older adult population such as: older adults who lost the ability to speak the Japanese language due to illness/medication (item 21), poor older women (item 23), older adults without pension (item 29), and older adults with physical disabilities (item 30). These items still speak to the second level of Maslowian hierarchy of needing security, while the other items such as lack of jobs (item 22), communication conflicts with the younger generation (item 25), and lack of intergenerational opportunities (item 27) reflect the fourth level of esteem needs. The latter can be translated as seeking activities at the micro-level where an older individual is considered valuable. Working is one way to feel productive and to contribute to society. Japan has one of the highest employment rates of older adults in the world, but the majority of jobs available for older adults are part-time, menial labor such as gatekeeping at highway tolls, building maintenance, and supermarket registers. One participant commented that in Chinatown, there were no jobs for older adults available besides cooks at Chinese restaurants. There is a need for a greater variety of jobs, which would utilize their unique skills and experience, and pay a better wage. Besides work, being valued from the younger generation is also a rewarding experience for older adults [31]. In the Confucian tradition, for example, older persons were considered wise and were respected by younger persons. Such a traditional relationship may be viewed as having dissipated in recent years, and older adults do not feel valued but are rather rejected by the young. Restricting one from activities such as work and intergenerational exchange can undermine the older adult's self-esteem.

By analyzing the priority items according to the Maslowian hierarchy, as the priorities descend from high to low, they reflect Maslow's order in ascending order from the second to fourth level. As indicated in previous literature, marginal groups are more likely to have lower level needs unmet. Older ethnic Chinese in Japan do have basic needs met, but still lack a sense of security of material resources which precludes them from ranking Maslowian third and higher order need items as higher priorities. They are at a higher risk of dependency, but unfortunately, they face barriers to access publicly available services due to a history of experiencing exclusion and services neglecting their 
cultural and language needs. Whether this was a concern for the majority of the ethnic Chinese, the next analysis comparing the needs with the city plan suggests that more needs addressed by the ethnic Chinese were similar to those of mainstream Japanese society. Seeking a match with the needs of the Chinese community to the existing aging policy framework was not a difficult task because most of their needs were also addressed as the needs of older Japanese. Table 2 indicates that much of the needs of the Yokohama Chinatown community are also addressed in the 4th Term Plan. In 2009, the City of Yokohama issued its 4th Term Plan for 2009-2011. Since the implementation of the national long-term care insurance program in the year 2000, the law mandates every local municipality to come up with a Health and Welfare Programs and Long-Term Care Insurance Program Plan, "...to clarify issues which need to be addressed and to plan comprehensively for the smooth implementation of the long-term care insurance system" [37]. The plan basically follows the rules written in the Social Welfare Law for the Elderly, and it matches the city's overall Health and Welfare Plan. The plan is developed once every three years and is generally a revision of the previous year's. For most of what is being planned by the city, regardless of nationality, all older adults have the right to access and utilize the services provided by the local municipality. If the services are provided under the national long-term care insurance program, all older adults must undergo a certification of eligibility regardless of nationality.

"Difficulty shopping" (item 1) is addressed as an issue in the 4th Term Plan under the title, "Provision of Services beyond the Long-Term Care Insurance Program." The City of Yokohama has started encouraging communities, social service agencies, and not-for-profits to provide driving and accompanying services for "shopping refugees" and although few in number, there are local initiatives being carried out. For example, in Konan Ward, a residential area of Yokohama, a long-term care agency provides, for a small fee based on the total weight of the items purchased, shopping assistance for ages 70 and older with special care needs.

There are a few cultural differences between the needs of the Chinese community and the Japanese society at large. Table 2 shows that there are six items unaddressed in the plan. They were related to issues stemming from the attitude and values influenced by the culture and history of the Chinese community in Japan. For example, there were issues related to finances and poverty among older adults (items 2, 4, 23, 29). In the plan, the local municipality states that they will subsidize service payments for low-income older adults, but that is as far it would go on helping low-income or poor older adults. In Japan, anti-poverty policy for all ages is fragmented; programs for low-income and poor persons are made up from policies from different ministries. The findings clearly showed that the policies and programs within the aging policy were divided despite the fact that the largest group on public assistance are the 603,000 older adult households, or $43 \%$ of the population on public assistance in 2010 [38]. Housing issues (item 4), for example, are under the auspices of the Ministry of Land, Infrastructure, Transport and Tourism and addressed in the Act on Provision and Promotion of Local Subsidized Housing (chiiki tokutei yuryo chintai jutaku), while issues related to impoverished elders (items 23 and 29) are under the same ministry as the long-term term care insurance program - the Ministry of Health, Labor and Welfare-but under the Public Assistance Act (seikatsu hogo ho). The challenge for solving the needs of low-income or poor older adults in Japan involved the coordination of various programs under separate laws. 
Coordination may be more difficult for older ethnic minorities due to cultural and language barriers. The needs assessment suggests that older ethnic Chinese refrain from using services (items 7 and 12). It is true that the Naka Ward, where Yokohama Chinatown is located, is one of the wards which does put a lot of effort into ameliorating the language barrier by publishing their newsletters in various languages and hiring a foreign-language speaker at the ward office. However, the Naka Ward social welfare council's report [39] indicated that council members were finding, "Communication with Chinese persons difficult due to difference in culture and way of thinking," and neighborhood volunteers, “...couldn't communicate at all during scheduled rounds of visit" of neighbors. There seemed to be more work in cultural competency needed at the neighborhood level in order to reach out properly to the Chinese-speaking neighbors, including language, awareness, and gaining trust.

In addition to the neighborhood level, care professionals also need to have cultural competency when dealing with older ethnic Chinese. The study participants have identified the lack of formal caregivers with ethnic Chinese background or competency in the ethnic Chinese culture and values (item 6). The plan does address the need for securing diversity in general terms but lacks the specificity of how the plan will serve ethnic minority elders. For example, the plan includes "Securing a diverse care workforce" by recruiting foreigners along with community residents, unemployed or retired persons, among others for the profession. Supporting them through the Economic Partnership Agreement (EPA) is the only specified goal for foreign candidates for the care workforce. As this study indicated, there was a need for care workers with cultural awareness, especially for Chinese and Korean elders, two of the largest ethnic populations which are also aging rapidly. Moreover, the need for cultural awareness was not limited to care workers, but also health professionals, too. Treatments for ethnic minorities may be different from the status quo. For example, a study examining Brazilian women's use of maternal health services suggested that they responded differently from Japanese women to anesthesia and sedatives, and concluded that Japanese health professionals need to be more prepared in knowing that treatment may differ depending on race and ethnicity [18].

Although the results indicate the importance of catering to Japan's aging services to the needs of older ethnic minorities, much of the existing policies are "one size fits all policies (item 26)" as addressed in the needs assessment. Japan does not have targeted policies for a particular race or ethnic group except for the Ainu, aborigines living on Hokkaido Island. As one municipal officer commented, a targeted policy for older ethnic minorities is unthinkable under the current system since much of the aging policy in Japan focuses on social security including pension, long-term care and health, and those policies are implemented as insurance-based programs which all citizens are required to contribute equally to the system, and redistributive justice and fairness are the underlying principles. Therefore, this study's endeavor to find concordance between the needs of ethnic minorities and the plan set forth by the local municipality becomes important so the needs can be met within the existing system. Since policies were written in general terms, the interpretative aspect becomes important in working with the Japanese policies. This will be an important task for social workers, researchers, and other aging-related professions advocating for the ethnic minority population.

There are limitations to the study. Firstly, the findings from this study are difficult to generalize with other ethnic Chinese communities in Japan, especially the newer communities, since most of the participants in this study were "older ethnic Chinese" who were the pioneers immigrating and settling in Yokohama, Japan when there were no diplomatic relationships between Japan and China. 
Comparatively, the "newer Chinese immigrant communities," emerging in various areas of Japan after Deng Xiao Ping's Open-Door Policy in the 1980s, were comprised of mainly Chinese students, scholars and businessmen. Their experiences may differ from generational and immigration status, and levels of acculturation [40], thus research outcomes may not be applicable to the "newer Chinese immigrants." Secondly, in addition to the City of Yokohama's plan, the local social welfare councils at the ward level - the lowest formal unit of community-oversee the local volunteerism and social welfare services, and create their own program plans. Since the long-term care insurance program is administered and executed at the ward level, it may be more appropriate to do so. However, for this study, the decision was made to look closely at the city plan because most of the study participants lived in different wards and the examination of the city plan would be more appropriate, as it served as a guideline for the lowest unit of analysis for community social welfare. The examination of the social welfare council's plans for the respective wards can be embarked upon as its own separate study in the future.

In summary, to the author's knowledge, this study is the first needs assessment of ethnic Chinese older adults in Japan. The Delphi method was applied to determine the priority level and consensus gained for the 30 needs identified by the community participants. Maslow's hierarchy of needs model guided the examination of the maturity of the community's political, economic and social environment in satisfying the needs of its older community members. It showed that the lowest order of basic need was not an issue, but the second order and above were all identified as high priority areas that required attention. Although this item has been matched with the second lowest order of securing resources, it can possibly lead to the lowest order of inability to satisfy the physiological need of attaining basic food and other items needed for daily living. Finally, the needs were matched with the city's Health and Welfare Programs and Long-Term Care Insurance Program Plan to see if the needs of ethnic Chinese were any different from the needs addressed by the Japanese society at large. The majority of the needs were similar to those of the Japanese citizens, but there were a few needs related to financial and cultural issues unique to the ethnic Chinese community in Japan. This study was able to document that Japanese society is not only aging rapidly, but aging with diversity. In order to achieve a "multicultural harmonious society" as set forth by the national government [41], local municipalities and their residents must work on attaining cultural awareness and competence, especially in the area of social welfare where it determines the maturity and the quality of life of the society they live in.

\section{Acknowledgments}

The author would like to thank the anonymous reviewers, as well as Kensei Hayashi and The Joint Council for Yokohama Chinatown's Community Development, Yu Kuo Chen and the Yokohama Cantonese Association, and the community of Yokohama Chinatown. Thank yo to the Nissay Foundation for funding this study.

\section{Conflicts of Interest}

The author declares no conflict of interest. 


\section{References}

1. Committee on Understanding Eliminating Racial Ethnic Disparities in Health Care. In Unequal Treatment: Confronting Racial and Ethnic Disparities in Health Care (with CD). Washington DC: The National Academies Press, 2003.

2. Vickie L. Shavers, Pebbles Fagan, Dionne Jones, William M.P. Klein, Josephine Boyington, Carmen Moten, and Edward Rorie. "The State of research on racial/ethnic discrimination in the receipt of health care.” American Journal of Public Health 102 (2012): 953-66.

3. Tamara R. Konetzka, and Rachel M. Werner. "Review: Disparities in long-term care." Medical Care Research and Review 66 (2009): 491-521.

4. David Barton Smith, Zhanlian Feng, Mary L. Fennell, Jacqueline S. Zinn, and Vincent Mor. "Separate and unequal: Racial segregation and disparities in quality across U.S. nursing homes." Health Affairs 26 (2007): 1448-58.

5. Daniel E. Jimenez, Stephen J. Bartels, Veronica Cardenas, Sanam S. Dhaliwal, and Margarita Alegría. "Cultural beliefs and mental health treatment preferences of ethnically diverse older adult consumers in primary care.” American Journal of Geriatric Psychiatry 20 (2012): 533-42.

6. Amanda Connolly, Elizabeth L. Sampson, and Nitin Purandare. "End-of-life care for people with dementia from ethnic minority groups: A systematic review." Journal of the American Geriatrics Society 60 (2012): 351-60.

7. Immigration Bureau. "Heisei 22 nen ni okeru gaikokujin torokusha tokei ni tsuite." Statistics on foreign registers in 2010. 2011. Available online: http://www.moj.go.jp/ (accessed on 28 June 2013). In Japanese

8. Immigration Bureau. "Kika. kyoka shinseishasu no suii (The trend on naturalization applicants)." 2012. Available online: http://www.moj.go.jp (accessed on 28 June 2013). In Japanese

9. Chunnam Kim. "The study on the life support service for the institutionalized Korean elderly dementia residents in Japan: Focused on the attitudes of the care workers in Japanese." Journal of Social Problems 54 (2004): 39-60.

10. Chunnam Kim. "Providing support to elderly foreigners living in Japan and Korea from multicultural perspectives: The practices of nursing homes for the Japanese living in Korea and Koreans living in Japan in Japanese.” Journal of Social Problems 59 (2010): 43-53.

11. Chunnam Kim. "Feasibility of providing support to elderly foreigners living in Care House in Japan: From the perspective of relocating elderly Koreans living in Japan to Care House." Journal of Social Problems 61 (2012): 49-58.

12. Jong Seong Moon. "The relationship between dementia and language among ethnic Korean elderly living in Japan.” Taisei Gakuin. University Bulletin 11 (2009): 119-26.

13. Jong Seong Moon. "The health status of ethnic Korean in Japan who use healthcare facility and day care center for the aged person.” Taisei Gakuin University Bulletin 14 (2012): 141-48.

14. Keita Hayama, Hyoichiro Araki, and Yoshihiro Kametani. "A study about residence environment in Nursing Homes of the Korean aged staying in Japan Part2." Summaries of Technical Papers of Annual Meeting Architectural Institute of Japan. E-2, Architectural Planning and Design II, Dwelling Houses and Housing Sites, Rural Planning, Education, 2001, 5714, pp. 315-16. In Japanese 
15. Taminori Takei, Hyoichiro Araki, and Yoshihiro Kametani. "The study of the life style foreign old people in Japanese." Architect. Institute of Japan Kinki Area Branch Research Report 41 (2001): 181-84.

16. Osamu Kunii, and Kazuo Nomiyama. "Present status of medical care for foreigners in Tochigi Prefecture, Japan: Survey at all clinics and hospitals." Japanese Journal of Hygiene 48 (1993): 677-84.

17. Pilar S. Sugimoto, Masako Ono-Kihara, Mitchell D. Feldman, and Masahiro Kihara. "Latin American immigrants have limited access to health insurance in Japan: A cross sectional study." BMC Public Health 12 (2012): 238.

18. Kinuko Sugiura. "Childrearing Brazilian women's perceptions of perinatal care, the healthcare system in Japan and related socio-cultural aspects: The third report." Maternal Health 50 (2009): 267-74.

19. Jiro Otsuru, Satoshi Abe, Kayoko Shinada, and Yoko Kawaguchi. "Oral health status in migrant workers.” Journal of the Japanese Society for Dental Health 53 (2003): 30-37.

20. Joseph M. Sirgy. "A quality-of-life theory derived from Maslow's developmental perspective." American Journal of Economics and Sociology 45 (2006): 329-42.

21. Abraham H. Maslow. Motivation and Personality, 2nd ed. New York: Harper \& Row, 1970.

22. Ronald J. Angel, Jacqueline L. Angel, and Terrence D. Hill. "Subjective control and health among Mexican-Origin elders in Mexico and the United States: Structural considerations in comparative research.” Journal of Gerontology: Social Sciences 64B (2009): 390-401.

23. Stephen M. Golant, and Rosemary McCaslin. "A functional classification of services for older persons.” Journal of Gerontological Social Work 1 (1979): 187-209.

24. Moji Wei, Jianliang Xu, Hongyan Yun, and Linlin Xu. "Ontology-based home service model." Computer Science and Information Systems 9 (2012): 813-38.

25. Ministry of Justice. "Kokuseki. (shusshinchi) betsu zairyu shikaku (zairyu mokuteki) betsu gaikokujin torokusha (Foreign registers by citizenship (native country) and certification of stay (purpose of stay)).” 2011. Available online: http://www.e-stat.go.jp (accessed on 27 June 2013). In Japanese

26. Ministry of Justice. "Kako 10 nen kan no kikoku kyoka shinseisha su, kika kyokasha su to no suii (Trend on number of naturalization applications and naturalized persons in the past 10 years)." 2012. Available online: http://www.moj.go.jp (accessed on 27 June 2013). In Japanese

27. Victor Minichiello, Rosalie Aroni, Eric Timewell, and Loris Alexander. In-depth Interviewing: Researching People. Melbourne, Australia: Longman Cheshire, 1990.

28. Gene Rowe, and George Wright. "The Delphi technique as a forecasting tool: Issues and analysis." International Journal of Forecasting 15 (1999): 351-81.

29. Denise Burnette, Nancy Morrow-Howell, and Li-Mei Chen. "Setting priorities for gerontological social work research: A national Delphi study." Gerontologist 43 (2003): 828-38.

30. Harold A. Linstone, and Murray Turoff. "The Delphi Method: Techniques and Applications." Upper Saddle River, NJ: Addison-Wesley Educational Publishers, 1975.

31. Li-Mei Chen. Productive aging in Japan. China Journal of Social Work 3 (2010): 165-80.

32. Nanako Tamiya, Haruko Noguchi, Akihiro Nishi, Michael R. Reich, Naoki Ikegami, Hideki Hashimoto, Kenji Shibuya, Ikegami Kawachi, and John Creighton Campbell. "Population 
ageing and wellbeing: Lessons from Japan's long-term care insurance policy.” Lancet 378 (2011): 1183-92.

33. Cabinet Office. "Koreisha. kaigo ni kansuru yoron chosa (National survey on elder caregiving)." 2005. Available online: http://www8.cao.go.jp (accessed on 28 June 2013). In Japanese

34. Ministry of Health, Labour and Welfare. "Indonesia, Philippines, Vietnam kara no gaikokujin kangoshi kaigo fukushishi kohosha no ukeire ni tsuite (Hosting foreign applicants as health aides and nurses from Indonesia, the Philippines, and Vietnam)." 2012. Available online: http://www.mhlw.go.jp (accessed on 28 June 2013). In Japanese

35. Ministry of Foreign Affairs. "Waga. kuni ni okeru kokusai kyoryoku NGO nado ni yoru fund raising hoho ni kakaru chosa (Survey on fundraising methods by NGOs for international cooperation and others in Japan).” 2006. Available online: http://www.mofa.go.jp (accessed on 28 June 2013). In Japanese

36. Ministry of Health, Welfare and Labour. Comprehensive Survey of Living Conditions, 2014. Available online: http://www.mhlw.go.jp/toukei/saikin/hw/k-tyosa/k-tyosa13/index.html (accessed on 1 May 2014).

37. City of Yokohama Health and Social Welfare Bureau. "4th Term Health and Welfare Programs and Long-term Care Insurance Program Plan.” Yokohama, Japan, 2009.

38. National Institute of Population and Social Security Research. "Hi hogojitsu setaisu/hogoritsu no nenji suii (Trend on number and rate of households on public assistance).” 2012. Available online: http://www.ipss.go.jp (accessed on 1 May 2014). In Japanese

39. City of Yokohama Naka Ward Council of Social Welfare. Naka Ward Community Health and Welfare Plan. Yokohama, Japan: Naka Ward Council of Social Welfare, 2006.

40. Wei Jiang, and Kiyomi Yamashita. "Residential concentration of Chinese newcomers in a publicapartment complex in the suburbs of Tokyo: A case of Kawaguchi Shinazono Danchi in Saitama.” Jinbunchirigaku. Kenkyu 29 (2005): 33-58. In Japanese

41. Ministry of Internal Affairs and Communication "Tabunka. kyosei no suishin ni kansuru kenkyukai hokokusho (Report from the study group on promoting multicultural symbiosis)." 2006. Available online: http://www.soumu.go.jp (accessed on 27 June 2013). In Japanese

(C) 2014 by the author; licensee MDPI, Basel, Switzerland. This article is an open access article distributed under the terms and conditions of the Creative Commons Attribution license (http://creativecommons.org/licenses/by/4.0/). 